\title{
Gross rearrangements of the MECP2 gene are found in both classical and atypical Rett syndrome patients
}

\author{
H L Archer, S D Whatley, J C Evans, D Ravine, \\ P Huppke, A Kerr, D Bunyan, B Kerr, E Sweeney, \\ S J Davies, W Reardon, J Horn, K D MacDermot, \\ R A Smith, A Magee, A Donaldson, Y Crow, \\ G Hermon, Z Miedzybrodzka, D N Cooper, L Lazarou, \\ R Butler, J Sampson, D T Pilz, F Laccone, A J Clarke
}

(3mG

This article is available free on JMG online via the JMG Unlocked open access trial, funded by the Joint Information Systems ST Committee. For further information, see LINE http://img.bmijournals.com/cgi/content/ full/42/2/97

\begin{abstract}
MECP2 mutations are identifiable in $\sim 80 \%$ of classic Rett syndrome (RTT), but less frequently in atypical RTT. We recruited 110 patients who fulfilled the diagnostic criteria for Rett syndrome and were referred to Cardiff for molecular analysis, but in whom an MECP2 mutation was not identifiable. Dosage analysis of MECP2 was carried out using multiplex ligation dependent probe amplification or quantitative fluorescent PCR. Large deletions were identified in $37.8 \%(14 / 37)$ of classic and $7.5 \%(4 / 53)$ of atypical RTT patients. Most large deletions contained a breakpoint in the deletion prone region of exon 4 . The clinical phenotype was ascertained in all 18 of the deleted cases and in four further cases with large deletions identified in Goettingen. Five patients with large deletions had additional congenital anomalies, which was significantly more than in RTT patients with other MECP2 mutations (2/193; $p<0.0001)$. Quantitative analysis should be included in molecular diagnostic strategies in both classic and atypical RTT.
\end{abstract}

$\mathrm{R}$ ett syndrome (RTT; MIM \#312750) is an X linked dominant neurological disorder of development, first described by Andreas Rett in 1966. It affects 1 in 10000 females and possibly 1 in 100000 males. $^{1-3}$ Classic RTT describes a characteristic presentation where all of the following clinical features are present: subtle abnormalities in development from birth, a period of stagnation, followed by regression with loss of hand and social skills and development of hand stereotypies, deceleration in head growth, severe learning difficulties, and gait dyspraxia..$^{4-6}$ By contrast, atypical RTT defines those patients who meet most, but not all, of the criteria of the classic picture yet still conform to the expected profile of the disorder. ${ }^{6}$

Pathological mutations in the MECP2 gene (MIM \#300005), which encodes methyl-CpG binding protein-2, were first reported in RTT in $1999 .{ }^{7}$ There are eight common mutations of this gene, which arise at CpG hotspots. ${ }^{7}$ MECP2 mutations are identifiable in $\sim 80 \%$ of classic RTT patients ${ }^{8-10}$ but less frequently in atypical RTT. ${ }^{11-16}$ The MECP2 gene contains four exons and encodes two major functional domains: the methyl binding domain (encoded by exons 3 and 4$)^{17}$ and the transcription repression domain (encoded by exon 4), which contains a nuclear localisation signal. ${ }^{18}$ The $M E C P 2$ gene is flanked at the $3^{\prime}$ end by the IRAKI gene and at the $5^{\prime}$ end by the OPNILW gene. The IRAKI gene has been postulated to play a role in atherosclerosis, ${ }^{19}$ whereas OPNILW gene variants have been associated with colour vision variation. ${ }^{20}$ The $M E C P 2$ translational initiation site was originally identified in exon 2 , but a second translation initiation site has recently been described in exon 1, which yields a new and predominant MeCP2 isoform. ${ }^{21}$ Mutations in exon 1 have been reported, ${ }^{22}$ although they are rare. ${ }^{23}$

Gross rearrangements of the $M E C P 2$ gene, which are not detectable by sequencing or denaturing high performance liquid chromatography (DHPLC), have been successfully identified using Southern blot analysis, ${ }^{162425}$ and more recently using dosage assays including quantitative fluorescent PCR (QF-PCR), ${ }^{26}$ real time PCR, ${ }^{26}$ and multiplex ligation dependent probe amplification (MLPA). ${ }^{27}$ So far, no gross rearrangements of the $M E C P 2$ gene causing RTT have been identifiable by fluorescent in situ hybridisation (FISH). ${ }^{28}$ In previous studies, quantitative methods have shown deletions in $\sim 29 \%$ of females with classical RTT who had no detectable MECP2 mutation by sequence analysis or DHPLC. ${ }^{16} 24-2729-32$

We investigated our cohort of RTT patients, in whom no $M E C P 2$ mutation had previously been detected by sequence analysis, for large deletions using QF-PCR or MLPA.

\section{METHODS}

\section{Patient recruitment}

Patients were recruited, with informed consent, from those referred to the Cardiff diagnostic laboratory for $M E C P 2$ analysis since 1999. Of 337 female patients recruited, 227 had a pathological mutation identified by sequencing exons 2,3 , and 4 of the MECP2 gene. Clinical data for these patients were ascertained through a clinical questionnaire. The remaining 110 patients, whose clinical phenotype was consistent with RTT, were recruited for quantitative analysis of the MECP2 gene. In addition to the Cardiff cohort, four patients with large deletions identified in Goettingen were recruited for $\mathrm{X}$ inactivation studies and clinical assessment.

Patients were designated either classic or atypical according to Hagberg criteria for RTT. ${ }^{63}$ As development in babies with RTT is abnormal from birth, the criteria were modified to take this into account. ${ }^{34}$ Common atypical features included preserved head growth (no departure from the birth centile), absence of regression, late regression (after 30 months), or the early onset of seizures (in the first 12 months of life or before regression). Where clinical data were insufficient to permit classification or data were

Abbreviations: DHPLC, denaturing high performance liquid chromatography; FISH, fluorescent in situ hybridisation; MLPA, multiplex ligation dependent probe amplification; QF-PCR, quantitative fluorescent PCR; RTT, Rett syndrome; TRD, transcription repression domain; UTR, untranslated region 
unavailable, patients were assigned to the "not classified" group.

\section{Molecular methods}

Exon 1 of the MECP2 gene was sequenced as previously described. ${ }^{23}$ Quantitative analysis was carried out using one of three dosage based assays to identify gross deletions of the MECP2 gene: QF-PCR (amplicons from exons 2, 3, and 4), real time PCR (amplicons from exons 2, 3, and 4) or MLPA (amplicons from exons 1, 2, 3, and 4 of the MECP2 gene and amplicons from the flanking genes IRAKI, LICAM, and SYBL1) (MRC Holland, Amsterdam) as previously described (fig l).23 2627

Analysis of X chromosome inactivation was performed in patients from both Cardiff and Goettingen with exonic deletions as described. ${ }^{35}$ In summary, lymphocyte genomic DNA was restricted with HpaII or McrBC enzymes prior to PCR amplification of the polymorphic CAG repeat of the androgen receptor (HUMARA) gene. Restriction fragments were run on an ABI 3100 DNA sequencer (Applied Biosystems) and peak areas compared.

\section{Clinical assessment}

All 18 Cardiff patients and 4 Goettingen patients in whom a deletion was identified were invited to attend for clinical assessment by one of the authors (HA), and this was accomplished for 11 patients. For the remaining patients, clinical information was collected by a questionnaire completed by the patient's physician or family. A severity score
Table 1 Results of MECP2 analysis in 337 female patients with RTT from the Cardiff study group

\begin{tabular}{llll}
\hline & $\begin{array}{l}\text { Classic } \\
\text { RTT } \\
(\mathbf{n}=1880)\end{array}$ & $\begin{array}{l}\text { Atypical } \\
\text { RTT } \\
(\mathbf{n}=123)\end{array}$ & $\begin{array}{l}\text { Not } \\
\text { classified } \\
(\mathbf{n}=\mathbf{2 6})\end{array}$ \\
\hline MECP2 mutation* & 143 & 58 & 26 \\
Dosage assay results & & & \\
$\quad$ Deletion & 14 & 4 & \\
Normal & 23 & 49 & \\
Fail/insufficient DNA & 8 & 12 & \\
\hline
\end{tabular}

*Identified by sequencing

(devised by AK), was assigned to each patient, scoring 0 , 1 , or 2 for each of the following: muscle tone, locomotor ability, feeding ability, seizures, and scoliosis, therefore the most severe score would be $10 .{ }^{36}$ The score generally increases until the age of 15 years and then plateaus. ${ }^{37}$

\section{RESULTS}

Large deletions of the MECP2 gene accounted for $37.8 \%$ (14/ 37) of classic RTT patients and 7.5\% (4/53) of atypical RTT patients where no mutation had been identified by sequencing of all four exons of the gene (table 1). Intra-exonic, single exon, and multi-exon deletions were found (fig 1). More than $80 \%$ of the deletions involved exons 3 and/or 4 (table 2). Of 14 deletions involving the 3' amplicon of exon 4 , four extended to involve the IRAKI gene. Large deletions

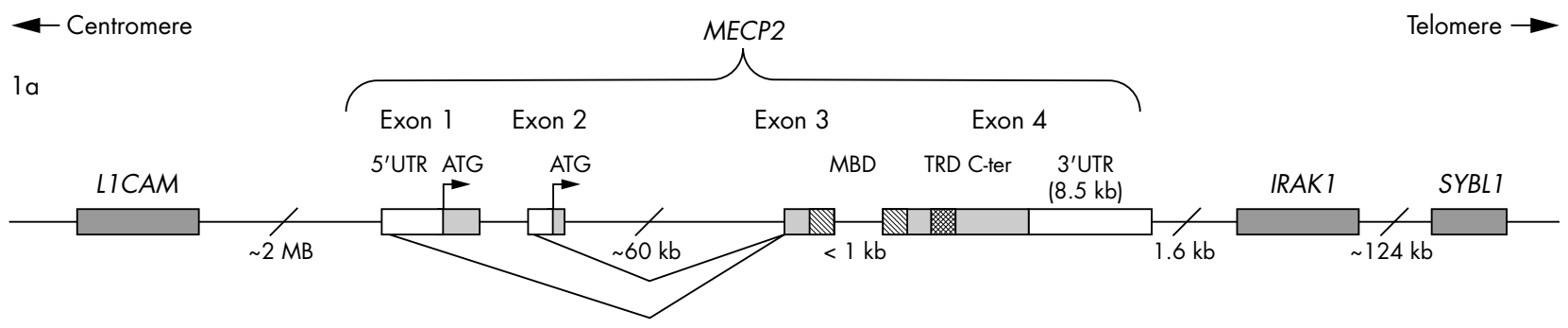

1b: Amplicon location

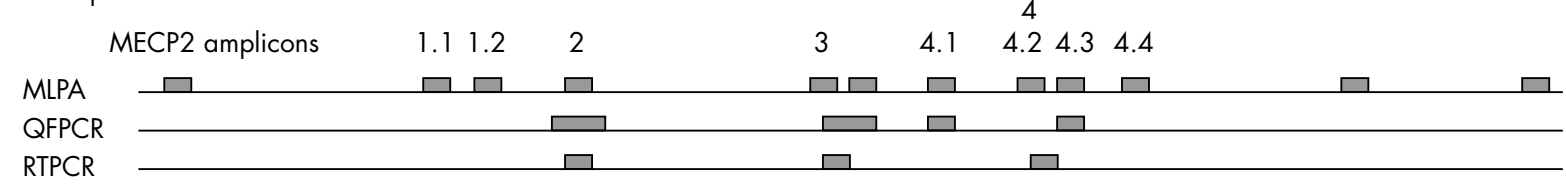

1c: Exonic deletions

Patient Deletion

$1 \quad$ Exon 1 and IRAK 1

2-4 Exon 1 and 2

5-7 Exon 3 and 4.1

8-10 Exon 3 and 4

$11-15$ Exon 3-4.3

16 Exon 4.1-4.3

17 Exon 4

18 Exon 4.2

19 Exon $4.2-4.3$

20 Exon $4.2-4.4$

$21 \quad$ Exon 4.3

22 Exon 4.3-IRAKI

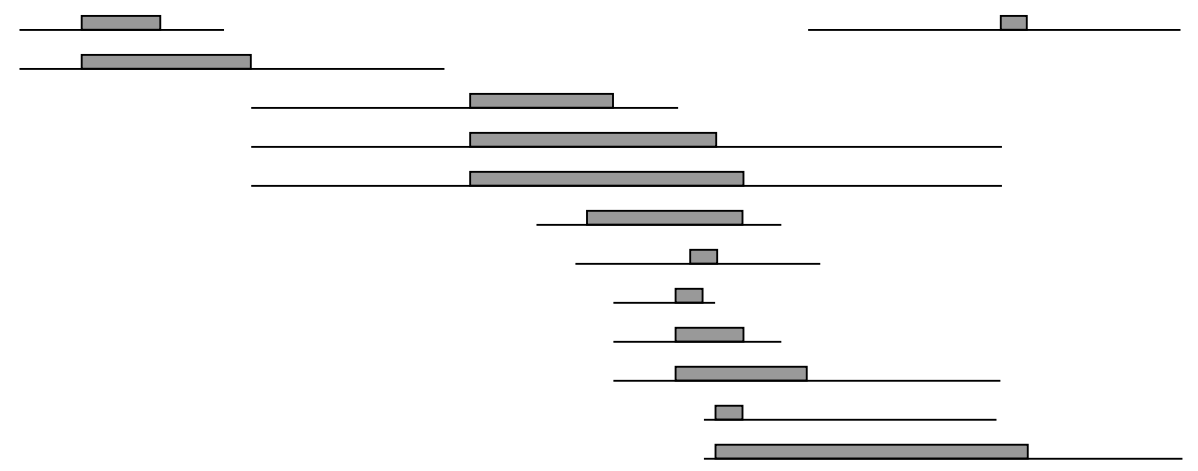

Figure 1 A representative diagram of single and multi-exonic deletions of the MECP2 gene identified in this study (not to scale). (A) MECP2 and adjacent genes are shown at the top of the diagram, with the exons of MECP2 shown in more detail. The methyl-binding domain (MBD), transcription repression domain (TRD), and untranslated regions (UTR) are in their approximate location. (B) The position of the amplicons used for quantitative analysis of MECP2 for each of the three methods: MLPA, QF-PCR, and real time PCR. (C) The extent of deletions identified is represented by a thick black bar. The broken line extending from the thick bars shows the unknown extent of each deletion. Note that the majority of the deletions include one potential breakpoint in the deletion prone region of exon 4 . 


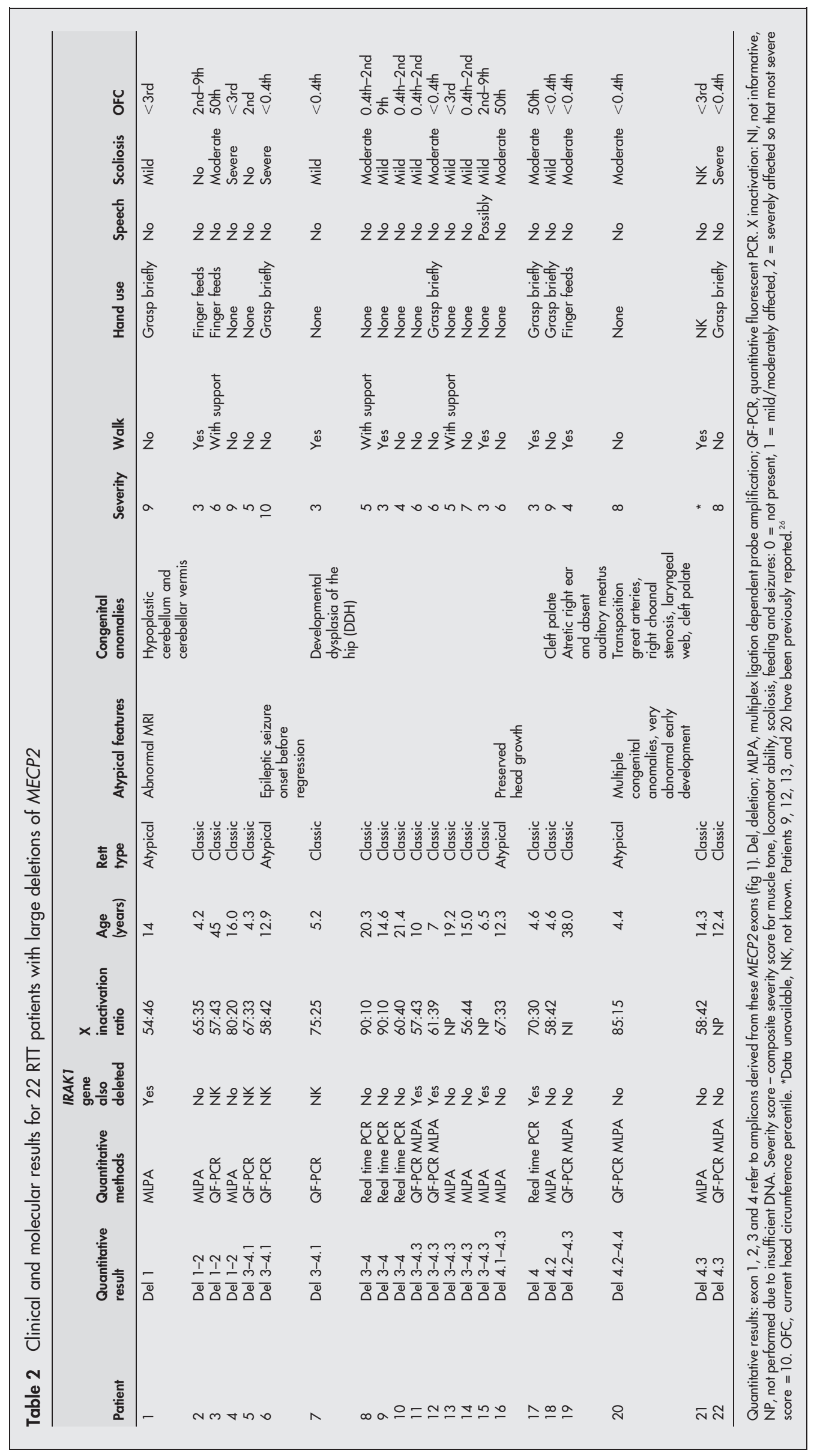




\begin{tabular}{|c|c|c|}
\hline Mutation & Frequency & $\begin{array}{l}\text { Proportion } \\
\text { of all } \\
\text { mutations }\end{array}$ \\
\hline R168X & 37 & $15.1 \%$ \\
\hline C-terminal deletions & 28 & $11.4 \%$ \\
\hline T158M & 25 & $10.2 \%$ \\
\hline R255X & 24 & $9.8 \%$ \\
\hline R270X & 19 & $7.8 \%$ \\
\hline R133C & 18 & $7.3 \%$ \\
\hline $\begin{array}{l}\text { Large exonic and } \\
\text { multi-exonic deletions }\end{array}$ & 18 & $7.3 \%$ \\
\hline R306C/R306H & 13 & $5.3 \%$ \\
\hline$R 294 X$ & 12 & $4.9 \%$ \\
\hline R106W/R106G & 12 & $4.9 \%$ \\
\hline Other & 39 & $15.9 \%$ \\
\hline Total & 245 & $100 \%$ \\
\hline
\end{tabular}

were among the most frequent $M E C P 2$ mutations in the whole Cardiff cohort, accounting for $7.3 \%$ of all mutations found (table 3).

$\mathrm{X}$ inactivation studies, in lymphocytes, were carried out on all Cardiff and Goettingen patients (22 patients in total) with large deletions. Analysis was informative for 16/22 patients with large $M E C P 2$ gene deletions and uninformative in one. DNA was insufficient for $\mathrm{X}$ inactivation analysis in three patients. $X$ inactivation was skewed more than $70 \%$ in six patients. The direction of skewing was not ascertained. Although numbers were insufficient for statistical analysis, there did appear to be a trend for those with skewing to be either more mildly or more severely affected (table 2 ).

Of all 22 patients ( 18 Cardiff, 4 Goettingen) with large MECP2 gene deletions, 18 had classic RTT, and 4 atypical RTT (table 2). Five patients had additional congenital anomalies, which in patients 1,19 , and 20 were considered to be severe (table 2, fig 2). Both patients with a cleft palate (patients 18 and 20) had normal G-banded karyotype and FISH studies showed a 22q11 microdeletion. The frequency of non-familial congenital anomalies was statistically significant when the Cardiff group with large deletions was compared with patients with other MECP2 mutations (Fisher's exact test, $\mathrm{p}<0.0001$ ).
All deletion patients had severe intellectual disability and most were unable to walk, use their hands, or speak. Only a single patient spoke one or two words with meaning. Over half of the deletion patients were microcephalic, which in three had been apparent from birth. All had marked hand stereotypies and only three were able to finger feed. Only seven patients could walk independently. All had abnormal muscle tone and dyspraxia. Scoliosis was reported in 19 cases. All had poor peripheral circulation, and breathing irregularity was present in all but one case. In the patients classified as atypical RTT, one had onset of seizures before regression, one had preserved head growth, one had complex congenital anomalies, and one had abnormal neuroimaging (table 2). The large deletion group were indistinguishable from other mutation positive Rett patients in terms of clinical severity.

\section{DISCUSSION}

Within this cohort of patients with Rett but without a mutation in MECP2 identified by sequencing, $37.8 \%$ of classic RTT and $7.5 \%$ of atypical RTT patients had deletions of the MECP2 gene, predominantly involving exons 3 and 4 . To our knowledge, this is the first study to determine the frequency of large deletions in patients with atypical RTT, and to highlight their importance in RTT patients with additional congenital anomalies.

Nine published studies have looked for large rearrangements of the MECP2 gene in patients with suspected RTT. ${ }^{16}{ }^{24-}$ ${ }^{27}{ }^{29-32}$ The frequency of large deletions in clinically defined classic RTT alone was $28.8 \%$ (30/104 patients). ${ }^{24-27} 29-31$ The overall deletion detection rate, combining results from published studies, in suspected RTT (classic, atypical, and unclassified) was $11.9 \%$ (26/218 patients). ${ }^{16}{ }^{25-27}$ The majority (140) of these patients were reported in one large study and were selected on the basis of having strongly suspected RTT rather than meeting diagnostic criteria for RTT; the need for careful clinical selection in future studies was highlighted by the authors. ${ }^{26}$ Another study found no deletions among a group of 17 patients selected only on the basis of referral for MECP2 analysis. ${ }^{31}$ The lower deletion frequencies found in these less well selected groups provide support for our policy of strict clinical selection on the basis of diagnostic criteria. We consider that the higher deletion frequency reported here
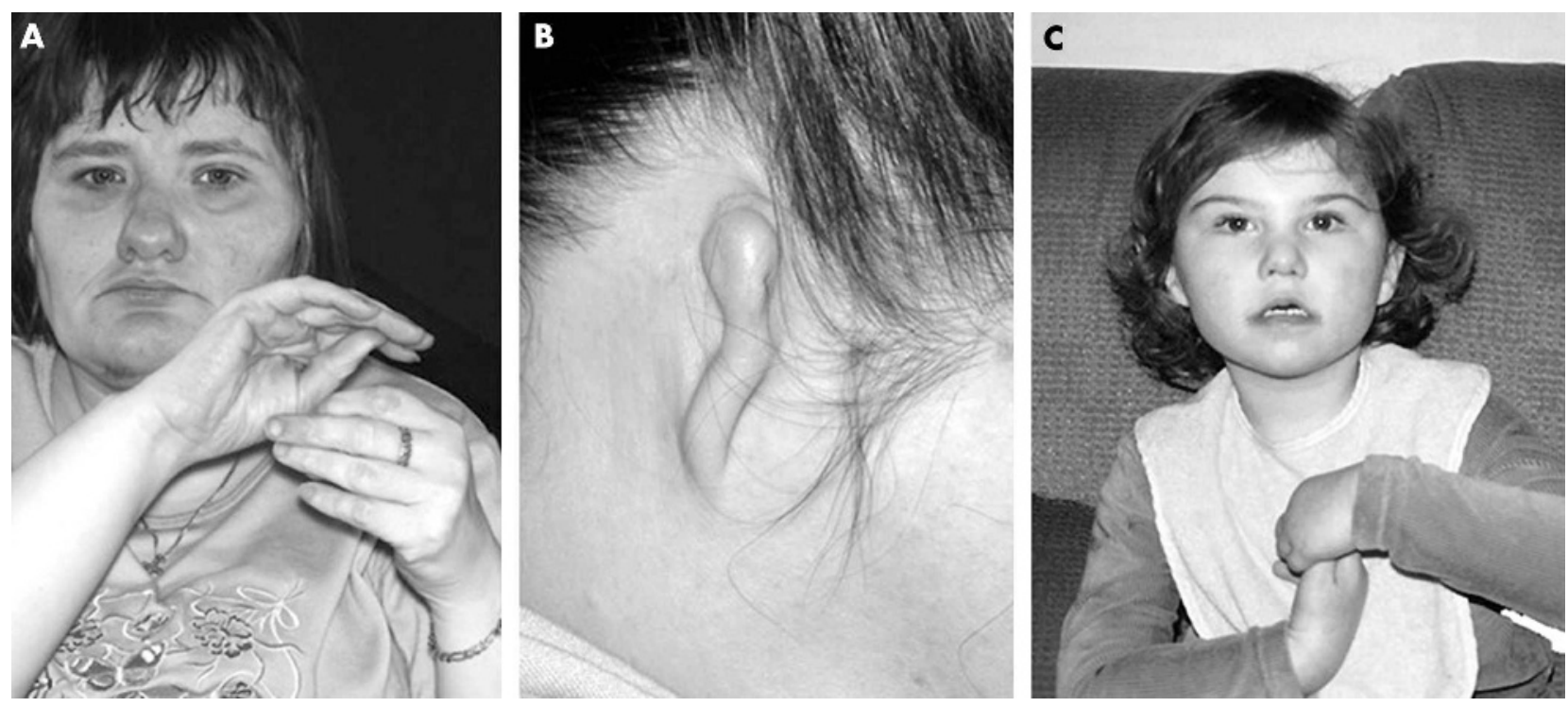

Figure 2 Photographs of patients 19 and 20 with severe congenital anomalies. (A) Patient 19; (B) atretic right ear of patient 19; (C) patient 20. 
is a more accurate reflection of the true deletion rate in clinically defined RTT.

Prior to this study, there was only one reported atypical RTT patient with a large deletion. ${ }^{26}$ Another atypical case had a duplication. ${ }^{29}$ One study looked for large deletions in patients with the preserved speech variant of RTT, but none was found, which suggests that they are rare in mild atypical presentations of RTT. ${ }^{25}$ The relative lack of gross rearrangements in atypical RTT could reflect patient selection bias in that classic RTT patients may constitute not only the most frequently studied group, but also the most intensively investigated group in terms of the MECP2 gene analysis performed. Our study has shown that large deletions of MECP2 are an important and frequent cause of atypical RTT.

Large deletions frequently involve either exon 4 or both exons 3 and 4 of the MECP 2 gene. They probably arise by unequal recombination caused by mispairing of homologous repetitive elements. ${ }^{26}$ There is a highly repetitive region in exon 4 of the $M E C P 2$ gene (deletion prone region), ${ }^{26}$ located $3^{\prime}$ to the TRD, where many intragenic deletion breakpoints occur (C-terminal deletions). Recombination between this and a second highly repetitive region, located in intron 2 , could be responsible for mediating the commonly identified large deletions encompassing both exons 3 and $4 .{ }^{26}$ It is likely that there are also recombinogenic repetitive elements in the 3'UTR which give rise to the large intragenic deletions noted in exon 4.

Late truncating mutations of the MECP2 gene arising $3^{\prime}$ to the TRD (in the terminal exon 4) are often associated with a milder clinical phenotype. ${ }^{1038}$ Therefore, it might be expected that the six patients with deletions involving only the 3' amplicons of exon 4 would have presented with a milder phenotype than that actually observed. However, detailed clinical information was only available for four patients. One patient had additional significant congenital anomalies, and also skewed $\mathrm{X}$ inactivation, and these factors probably added to the severity of her phenotype. The remaining patients had classic RTT, with two patients retaining the ability to walk, and one older patient still able to walk with support. A $3^{\prime}$ terminal exon 4 deletion would be predicted to lead to $(a)$ loss of the termination codon in all cases and $(b)$ loss of at least one of the polyadenylation sites in most cases. Although the consequences at the level of protein expression of large 3' terminal MECP2 deletions are unknown, such mutations are likely to disrupt the secondary structure of mRNA with resultant mRNA instability. Whether large deletions invariably constitute a null mutation or whether some residual functional MeCP2 protein may be present in certain cases still remains to be determined. No clear relationship was apparent between clinical severity and exonic deletions arising distal to the TRD in this study.

In our study, five patients had additional congenital anomalies, accounting for $22.7 \%$ of those with large deletions; four had deletions involving the $3^{\prime}$ end of exon 4. The increased frequency of additional congenital anomalies in Cardiff cases with gross $M E C P 2$ deletions (5/18) compared with RTT patients with any other MECP2 mutations (2/193), was statistically significant. Some deletions are likely to involve complex deletion/insertion events, ${ }^{26}$ and the potential disruption of a second gene by the inserted fragment. Extension of the deletion into the adjacent IRAKl gene, and potentially other genes in the immediate vicinity, may also play a role in extending the observable phenotype. We suggest that the complex nature of the mutation underlying some large deletions is manifesting in the additional anomalies found in this subset of patients with RTT.

\section{Clinical relevance}

Our results have indicated that large deletions of the MECP2 gene are an important and frequent cause of both atypical and classic RTT. Such deletions may be found in patients with additional congenital anomalies and features of RTT. Quantitative analysis of the MECP2 gene is an important part of the diagnostic assessment of all patients with clinically confirmed RTT in whom MECP2 gene sequence analysis has not demonstrated a mutation.

\section{ACKNOWLEDGEMENTS}

We thank all the families who have taken part in the Cardiff Rett Study. We are also grateful to all the UK Regional Genetics Services and paediatric services who contributed the majority of the clinical data for this study. Images of patient 19 were taken by the Medical Illustration Department, Royal Gwent Hospital, Newport. This work was supported by The Health Foundation, a health care charity.

\section{Authors' affiliations}

H L Archer, J C Evans, D N Cooper, J Sampson, A J Clarke, Cardiff University, Institute of Medical Genetics, University Hospital of Wales, Cardiff, UK

S D Whatley, University Hospital of Wales, Department of Medical Biochemistry, Cardiff, UK

D Ravine, University of Western Australia, Department of Human Genetics, Perth, Australia

P Huppke, Universität Göttingen, Department of Neuropaediatrics, Göttingen, Germany

A Kerr, Glasgow University, Department of Psychological Medicine, Glasgow, UK

D Bunyan, National Reference Genetics Laboratory (Wessex), Salisbury, UK

B Kerr, St Mary's Hospital, Department of Medical Genetics,

Manchester, UK

E Sweeney, Liverpool Children's Hospital, Department of Clinical Genetics, Liverpool, UK

S J Davies, L Lazarou, R Butler, D T Pilz, University Hospital of Wales, Institute of Medical Genetics, Cardiff, UK

W Reardon, Our Lady's Hospital for Sick Children, National Centre for Medical Genetics, Crumlin, Dublin, Ireland

J Horn, Bangor University, Department of Paediatrics, Bangor, UK

K D MacDermot, Imperial College, Kennedy-Galton Centre, London, UK

R A Smith, York District Hospital, Department of Paediatrics, York, UK

A Magee, Belfast City Hospital, Northern Ireland Regional Genetics Service, Belfast, UK

A Donaldson, Bristol Hospital for Sick Children, Department of Clinical Genetics, Bristol, UK

Y Crow, St James' University Hospital, Department of Medical Genetics, Leeds, UK

G Hermon, The Children's Trust, St Margaret's School, Surrey, UK

Z Miedzybrodzka, Aberdeen Medical School, Department of Medicine and Therapeutics, Foresterhill, Aberdeen, UK

F Laccone, Universität Göttingen, Institut für Humangenetik, Göttingen, Germany

Competing interests: there are no competing interests.

Ethics approval was granted by MREC (Wales): reference 02/9/33.

Correspondence to: Dr H Archer, Institute of Medical Genetics, Cardiff University, University Hospital of Wales, Heath Park, Cardiff CF14 4XN, UK; archerhl@cardiff.ac.uk

Received 31 March 2005

Revised version received 18 August 2005

Accepted for publication 6 September 2005

Published Online First 14 October 2005

\section{REFERENCES}

1 Kerr AM, Stephenson JB. A study of the natural history of Rett syndrome in 23 girls. Am J Med Genet 1986; 1:S77-83.

2 Hagberg B, Hagberg G. Rett syndrome: epidemiology and geographical variability. Eur Child Adolesc Psychiatry 1997;6:S5-7.

3 Kozinetz CA, Skender ML, MacNaughton N, Almes MJ, Schultz RJ, Percy AK, Glaze DG. Epidemiology of Rett syndrome: a population-based registry. Pediatrics 1993;91:445-50. 
4 Hagberg B, Aicardi J, Dias K, Ramos O. A progressive syndrome of autism, dementia, ataxia, and loss of purposeful hand use in girls: Rett's syndrome: report of 35 cases. Ann Neurol 1983;14:471-9.

5 The Rett Syndrome Diagnostic Criteria Work Group. Diagnostic criteria for Rett syndrome. Ann Neurol 1988;23:425-8.

6 Kerr AM, Nomura Y, Armstrong D, Anvret M, Belichenko PV, Budden S, Cass H, Christodoulou J, Clarke A, Ellaway C, D'Esposito M, Francke U,' Hulten M, Julu P, Leonard H, Naidu S, Schanen C, Webb T, Engerstrom IW, Yamashita Y, Segawa M. Guidelines for reporting clinical features in cases with MECP2 mutations. Brain Dev 2001;23:208-11.

7 Amir RE, Van dV, I, Wan M, Tran CQ, Francke U, Zoghbi HY. Rett syndrome is caused by mutations in X-linked MECP2, encoding methyl-CpG-binding protein 2. Nat Genet 1999;23:185-8.

8 Dragich J, Houwink-Manville I, Schanen C. Rett syndrome: a surprising result of mutation in MECP2. Hum Mol Genet 2000;9:2365-75.

9 Cheadle JP, Gill H, Fleming N, Maynard J, Kerr A, Leonard H, Krawczak M, Cooper DN, Lynch S, Thomas N, Hughes H, Hulten M, Ravine D, Sampson JR, Clarke A. Long-read sequence analysis of the MECP2 gene in Rett syndrome patients: correlation of disease severity with mutation type and location. Hum Mol Genet 2000;9:1119-29.

10 Kammoun F, De Roux N, Boespflug-Tanguy O, Vallee L, Seng R, Tardieu M, Landrieu P. Screening of MECP2 coding sequence in patients with phenotypes of decreasing likelihood for Rett syndrome: a cohort of 171 cases. J Med Genet 2004;41:e85.

11 Amir RE, Zoghbi HY. Rett syndrome: methyl-CpG-binding protein 2 mutations and phenotype-genotype correlations. Am J Med Genet 2000;97: 147-52.

12 Bienvenu T, Carrie A, De Roux N, Vinet MC, Jonveaux P, Couvert P, Villard L, Arzimanoglou A, Beldjord C, Fontes M, Tardieu M, Chelly J. MECP2 mutations account for most cases of typical forms of Rett syndrome. Hum Mol Genet 2000;9:1377-84.

13 Hoffbuhr K, Devaney JM, LaFleur B, Sirianni N, Scacheri C, Giron J, Schuette J, Innis J, Marino M, Philippart M, Narayanan V, Umansky R, Kronn D, Hoffman EP, Naidu S. MeCP2 mutations in children with and without the phenotype of Rett syndrome. Neurology 2001;56:1486-95.

14 Huppke P, Laccone F, Kramer N, Engel W, Hanefeld F. Rett syndrome: analysis of MECP2 and clinical characterization of 31 patients. Hum Mol Genet 2000:9:1369-75.

15 Lee SS, Wan M, Francke U. Spectrum of MECP2 mutations in Rett syndrome. Brain Dev 2001;23:S138-43.

16 Bourdon V, Philippe C, Labrune O, Amsallem D, Arnould C, Jonveaux P. A detailed analysis of the MECP2 gene: prevalence of recurrent mutations and gross DNA rearrangements in Rett syndrome patients. Hum Genet 2001; 108:43-50.

17 Nan X, Meehan RR, Bird A. Dissection of the methyl-CpG binding domain from the chromosomal protein MeCP2. Nucleic Acids Res 1993;21:4886-92.

18 Nan X, Campoy FJ, Bird A. MeCP2 is a transcriptional repressor with abundant binding sites in genomic chromatin. Cell 1997:88:471-81.

19 Huang Y, Li T, Sane DC, Li L. IRAK1 serves as a novel regulator essential for lipopolysaccharide-induced interleukin-10 gene expression. J Biol Chem 2004;279:51697-703.

20 Verrelli BC, Tishkoff SA. Signatures of selection and gene conversion associated with human color vision variation. Am J Hum Genet 2004;75:363-75

21 Warby S. Discovery of a new protein isoform of $\mathrm{MeCP} 2$ and exon 1 mutations causing Rett syndrome. Clin Genet 2004;66:108-10.

22 Mnatzakanian GN, Lohi H, Munteanu I, Alfred SE, Yamada T, MacLeod PJ, Jones JR, Scherer SW, Schanen NC, Friez MJ, Vincent JB,
Minassian BA. A previously unidentified MECP2 open reading frame defines a new protein isoform relevant to Rett syndrome. Nat Genet 2004;36:339-41.

23 Evans JC, Archer HL, Whatley SD, Kerr A, Clarke A, Butler R. Variation in exon 1 coding region and promoter of MECP2 in Rett syndrome and controls. Eur J Hum Genet 2005;13:124-6.

24 Yaron Y, Ben Zeev B, Shomrat R, Bercovich D, Naiman T, Orr-Urtreger A. MECP2 mutations in Israel: implications for molecular analysis, genetic counseling, and prenatal diagnosis in Rett syndrome. Hum Mutat 2002;20:323-4.

25 Schollen E, Smeets E, Deflem E, Fryns JP, Matthiis G. Gross rearrangements in the MECP2 gene in three patients with Rett syndrome: implications for routine diagnosis of Rett syndrome. Hum Mutat 2003;22:116-20.

26 Laccone F, Junemann I, Whatley S, Morgan R, Butler R, Huppke P, Ravine D. Large deletions of the MECP2 gene detected by gene dosage analysis in patients with Rett syndrome. Hum Mutat 2004;23:234-44.

27 Erlandson A, Samuelsson L, Hagberg B, Kyllerman M, Vujic M, Wahlstrom J. Multiplex ligation-dependent probe amplification (MLPA) detects large deletions in the MECP2 gene of Swedish Rett syndrome patients. Genet Test 2003;7:329-32.

28 Bourdon V, Philippe C, Grandemenge A, Reichwald K, Jonveaux P. Deletion screening by fluorescence in situ hybridization in Rett syndrome patients. Ann Genet $2001 ; 44: 191-4$

29 Erlandson A, Hallberg B, Hagberg B, Wahlstrom J, Martinsson T. MECP2 mutation screening in Swedish classical Rett syndrome females. Eur Child Adolesc Psychiatry 2001;10:117-21

30 Ariani F, Mari F, Pescucci C, Longo I, Bruttini M, Meloni I, Hayek G, Rocchi R, Zappella M, Renieri A. Real-time quantitative PCR as a routine method for screening large rearrangements in Rett syndrome: Report of one case of MECP2 deletion and one case of MECP2 duplication. Hum Mutat 2004;24:172-7.

31 Ravn K, Nielsen JB, Skjeldal OH, Kerr A, Hulten M, Schwartz M. Large genomic rearrangements in MECP2. Hum Mutat 2005;25:324.

32 Huppke $P$, Ohlenbusch A, Brendel C, Laccone F, Gartner J. Mutation analysis of the HDAC 1,2 8 and CDKL5 genes in Rett syndrome patients without mutations in MECP2. Am J Med Genet 2005;137:136-8.

33 Allen RC, Zoghbi HY, Moseley AB, Rosenblatt HM, Belmont JW. Methylation of Hpall and Hhal sites near the polymorphic CAG repeat in the human androgen-receptor gene correlates with $\mathrm{X}$ chromosome inactivation. Am J Hum Genet 1992;51:1229-39.

34 Hagberg B, Hanefeld F, Percy A, Skjeldal O. An update on clinically applicable diagnostic criteria in Rett syndrome. Comments to Rett Syndrome Clinical Criteria Consensus Panel Satellite to European Paediatric Neurology Society Meeting, Baden Baden, Germany, 11 September 2001. Eur J Paediatr Neurol 2002;6:293-7.

35 Einspieler C, Kerr AM, Prechtl HF. Is the early development of girls with Rett disorder really normal? Pediatr Res 2005;57:696-700.

36 Kerr AM, Belichenko P, Woodcock T, Woodcock M. Mind and brain in Rett disorder. Brain Dev 2001;23:S44-9.

37 Kerr AM, Prescott R. Predictive value of the early signs in Rett disorder. Brain Dev 2005;27(suppl):S20-4.

38 Smeets E, Terhal P, Casaer P, Peters A, Midro A, Schollen E, van Roozendaal K, Moog U, Matthijs G, Herbergs J, Smeets $H$, Curfs L, Schrander-Stumpel C, Fryns JP. Rett syndrome in females with CTS hot spot deletions: a disorder profile. Am J Med Genet $2005 ; 132: 117-20$ 